\title{
Clara cell protein as a marker of Clara cell damage and bronchoalveolar blood barrier permeability
}

\author{
C. Hermans*, B. Knoops*, M. Wiedig**, K. Arsalane*, G. Toubeau**, P. Falmagne ${ }^{+}$, A. Bernard*
}

Clara cell protein as a marker of Clara cell damage and bronchoalveolar blood barrier permeability. C. Hermans, B. Knoops, M. Wiedig, K. Arsalane, G. Toubeau, P. Falmagne, A. Bernard. (C) ERS Journals Ltd 1999.

ABSTRACT: The $16 \mathrm{kDa}$ Clara cell protein (CC16), an abundant component of airway secretions, has recently been proposed in humans as a pulmonary marker measurable not only in bronchoalveolar lavage fluid (BALF) but also in serum. The aim of the present study was to investigate the changes and determinants of CC16 concentrations in these fluids in normal rats and rats with lung injury.

Female Sprague-Dawley rats were given a single $i$.p. injection of arachis oil $(\mathrm{n}=\mathbf{2 0})$ or chemicals in arachis oil $(n=10)$ that mainly damage Clara cells (4-ipomeanol (IPO) $8 \mathrm{mg} \cdot \mathrm{kg}^{-1}$ and methylcyclopentadienyl manganese tricarbonyl (MMT) $5 \mathrm{mg} \cdot \mathrm{kg}^{-1}$ ) or endothelial cells ( $\alpha$-naphthylthiourea (ANTU) $5 \mathrm{mg} \cdot \mathrm{kg}^{-1}$ ).

CC16 concentration (mean $\pm S D$ in $\mu \mathrm{g} \cdot \mathrm{L}^{-1}$ ), measured by a sensitive latex immunoassay, was significantly reduced in BALF of all treated groups (IPO $380 \pm 100$; MMT $730 \pm 200 ;$ ANTU 1,070 \pm 200 ; controls $1,700 \pm 470$ ). The same pattern of decrease was observed in the labelling of Clara cells with an anti-CC16 antiserum as well as in the CC16 messenger ribonucleic acid levels assessed by Northern enzyme-linked immunosorbent assay. In serum, by contrast, $\mathrm{CC16}$ was significantly increased in all treated groups (IPO 31 \pm 7 ; MMT 22 \pm 12 ; ANTU 52 \pm 24 ; controls 15 \pm 6 ). This rise of CC16 in serum was associated with an elevation of albumin in BALF which is an index of increased bronchoalveolar/blood barrier permeability.

In conclusion, lung injury induces a decrease of the $16 \mathrm{kDa}$ Clara cell protein in bronchoalveolar lavage fluid owing to a reduced production by damaged Clara cells, and an increase in serum protein levels resulting from its enhanced leakage across the bronchoalveolar/blood barrier. This study provides new insights into the understanding of the changes of lung secretory proteins in bronchoalveolar lavage fluid and serum.

Eur Respir J 1999; 13: 1014-1021.

Clara cell protein, a microprotein of $16 \mathrm{kDa}(\mathrm{CC} 16)$, is one of the major secretory products of Clara cells which are nonciliated cells of the bronchiolar epithelium [1]. Human and animal studies have shown that CC16 occurs in high concentrations in bronchial and bronchoalveolar lavage fluids (BALF), reflecting the intense secretion of this protein into the lumen of the respiratory tract [2-5]. Interestingly, $\mathrm{CC} 16$ also occurs in serum derived from the respiratory tract, probably by passive diffusion $[2,5]$.

Recent studies in humans suggest that CC16 levels in serum and BALF are influenced by different factors, the contributions of which are still poorly understood. In smokers, for instance, a decrease in CC16 levels has been found in BALF and serum which has been ascribed to Clara cell damage induced by tobacco smoke [3, 6]. By contrast, in patients with interstitial lung disorders or firefighters acutely exposed to fire smoke, the CC16 levels in serum were found to be increased [7-9]. The most likely explanation for this elevation appears to be an increased leakage of the protein from the respiratory tract into the bloodstream across the bronchoalveolar/blood barrier (BA/BB), although other mechanisms such as a stimulated synthesis cannot be ruled out.
*Unit of Industrial Toxicology and Occupational Medicine, Faculty of Medicine, Catholic University of Louvain, Belgium **Dept of Histology and ${ }^{+}$Dept of Biological Chemistry, University of MonsHainaut, Belgium.

\section{Correspondence: C. Hermans}

Unit of Industrial Toxicology and Occupational Medicine

Faculty of Medicine

Catholic University of Louvain

30.54 Clos Chapelle-aux-Champs

B-1200 Brussels

Belgium

Fax: 3227643228

Keywords: Bronchoalveolar blood barrier Clara cell protein

lung epithelial cell lung injury

lung marker

Received: April 241998

Accepted after revision January 291999

This study was supported by the European Union (EV4-CT96-0171) and the National Fund for Scientific Research (Belgium).
To explore the mechanisms underlying $\mathrm{CC} 16$ changes in BALF and serum, CC16 was traced from its synthesis by Clara cells to its passage into serum in normal rats and rats treated with well-known pneumotoxicants affecting predominantly Clara cells (4-ipomeanol (IPO), methylcyclopentadienyl manganese tricarbonyl (MMT)) [10-15] and endothelial cells ( $\alpha$-naphthylthiourea (ANTU)) [15-17]. The changes of CC16 in BALF and serum were compared with lung histology, Clara cell density, CC16 gene expression, and classical indices of lung injury.

\section{Materials and methods}

Animals

All experiments were performed on adult female Sprague-Dawley rats (B\&K Universal Ltd., North Humberside, UK) weighing 170-250 g. The animals were treated in compliance with the guidelines edicted by the Belgian Ministry of Middle Class and Agriculture. Throughout the study, the animals were housed in an air-conditioned room $\left(25^{\circ} \mathrm{C}, 50 \%\right.$ relative humidity $)$ with a regular $12 \mathrm{~h}$ light/dark cycle and were allowed standard chow and tap water ad libitum. 


\section{Source of reagents}

IPO was kindly provided by M.R. Boyd (National Cancer Institute, Bethesda, MD, USA) and ANTU by G. Saumon (Institut National de la Santé et de la Recherche Médicale, Faculté Xavier Bichat, Paris, France). MMT was obtained from Aldrich Chemicals (Milwaukee, WI, USA). The rabbit polyclonal anti-CC16 antibody raised against purified rat Clara cell protein was produced in the authors laboratory and checked for its specificity towards its antigen, as described previously [5]. Biotinylated goat anti-rabbit immunoglobulin $(\mathrm{Ig}) \mathrm{G}$ antiserum, biotinylated rabbit anti-mouse IgG antiserum and avidin biotinylated enzyme complex (ABC) were purchased from Dakopatts (Glostrup, Denmark). All other reagents were of analytical grade and supplied by normal commercial sources.

\section{Treatments}

The compounds used in this study were chosen because of their ability to produce selective pulmonary toxicity in rats following parenteral administration. For each experimental group $(n=10)$, the lowest dose and the shortest delay before sacrifice required for biochemical and morphological changes without lethality and toxic effects on organs other than the lung was chosen. Chemicals were administered in arachis oil $\left(1 \mathrm{~mL} \cdot \mathrm{kg}^{-1}\right)$ as a single intraperitoneal injection at the dose of 8 (IPO) or $5 \mathrm{mg} \cdot \mathrm{kg}^{-1}$ (ANTU and MMT). Control animals $(n=20)$ were given arachis oil only and processed along with treated rats.

\section{Sacrifice and sample collection}

Six hours after treatment with ANTU or MMT, and $24 \mathrm{~h}$ following IPO administration, the animals were sacrificed by an i.p. injection of sodium pentobarbital $\left(60 \mathrm{mg} \cdot \mathrm{kg}^{-1}\right)$. The trachea was cannulated when respiration had ceased and the lungs were washed 4-times with $10 \mathrm{~mL}$ sterile $0.9 \%(\mathrm{w} / \mathrm{v}) \mathrm{NaCl}$. The BALF was centrifuged $(2,000 \times g$ for $10 \mathrm{~min}$ at $4{ }^{\circ} \mathrm{C}$ ) and the resultant cell-free supernatant analysed for the different biochemical parameters. Following aortic cannulation, whole blood was collected and stored at $4{ }^{\circ} \mathrm{C}$ for $3 \mathrm{~h}$. After centrifugation of the clotted blood at $2,000 \times g$ for $10 \mathrm{~min}$, the sera were stored at $-20^{\circ} \mathrm{C}$ until analysis.

\section{Morphological examination}

Immediately after sacrifice, lung samples were fixed by immersion in 4\% formaldehyde or in Bouin's fluid for at least $48 \mathrm{~h}$. Fixed tissues were rinsed in $70 \%$ ethanol, routinely dehydrated in graded ethanol and in butanol, and embedded in Paraplast Plus B); (Sherwood Medical Company, St Louis, MO, USA) paraffin according to standard procedures [18]. Paraffin sections of 4-5 $\mu \mathrm{m}$ thickness were cut serially with a Reichert Autocut 2040 microtome (Reichert, Nussloch, Germany) and mounted on silanecoated glass slides. For each specimen, selected sections were stained with Masson's trichrome or with haematoxylin, erythrosin, orange $G$ and anilin blue. To observe consecutive fields, the remaining adjacent slides were saved for immunocytochemical labelling.

CC16-containing cells were localized in lung sections with a rabbit polyclonal antibody raised against rat $\mathrm{CC} 16$ using a slightly modified streptavidin-biotin immunoper- oxidase method $[5,18]$. Briefly, before immunostaining, rehydrated sections were immersed in $0.4 \%$ hydrogen peroxide for $5 \mathrm{~min}$ and pretreated by incubation in a wet autoclave at $120^{\circ} \mathrm{C}$ for $20 \mathrm{~min}$ for antigen retrieval [19]. Prior to immunostaining, the pretreated sections were washed in phosphate-buffered saline (PBS; $0.04 \mathrm{M} \mathrm{Na}_{2} \mathrm{HPO}_{4}$, $\left.0.01 \mathrm{M} \mathrm{KH}_{2} \mathrm{PO}_{4}, 0.12 \mathrm{M} \mathrm{NaCl}, \mathrm{pH} 7.4\right)$ and incubated in $5 \%$ normal goat serum (NGS) in PBS for $20 \mathrm{~min}$. Slides were then rinsed and incubated sequentially at room temperature in the following solutions: 1) rabbit polyclonal anti-rat CC16 (1:400) for $1 \mathrm{~h}$; 2) biotinylated goat antirabbit IgG (1:50) for 20 min; and 3) ABC complexes for $20 \mathrm{~min}$. Bound peroxidase activity was visualized by incubation with $0.02 \% 3,3^{\prime}$-diaminobenzidine and $0.01 \%$ $\mathrm{H}_{2} \mathrm{O}_{2}$ in PBS. The different solutions were prepared in $5 \%$ NGS-PBS buffer ( $\mathrm{pH} 7.4)$ and after each step of the immunostaining procedure the sections were rinsed in the same buffer. The sections were finally counterstained with haemalum and luxol fast blue, dehydrated and mounted with a permanent mounting medium.

Control of the specificity of immunolabellings included the omission of the primary antibody or the substitution of the primary antibody with nonimmune serum. In each case, these assays confirmed the specificity of the observed immunolabellings. In addition, the antiserum used in this study was checked to ensure that it gave clear-cut immunostaining patterns on control lung sections i.e. the labelling was restricted to Clara cells.

Morphometric analysis was performed by a computerassisted approach as described previously [20]. Briefly, the procedures utilized a hardware consisting of a high-resolution colour video camera (JVC KY-15; Tokyo, Japan) mounted on a Zeiss Axioplan microscope and connected to an IBM-compatible PC (Compaq 80386; Alcatel TITN, Grenoble, France). The software was specifically designed for colour analysis and morphometry (Système d'Analyses Microscopiques à Balayage Automatique (SAMBA) system; Alcatel). The analysis of CC16-immunoreactive cells was performed on one lung section per experimental animal by scanning 10 bronchiolar profiles (terminal bronchioles) taken at random in the tissue section at $200 \times$ magnification. This represented a total scanned surface of $\sim 40,000 \mu \mathrm{m}^{2}$ of bronchiolar epithelium. In order to define the bronchiolar surface to be analysed, the basal membrane and the apical border of each bronchiolar section were demarcated interactively. The area of the bronchiolar epithelium was then automatically measured with an appropriate program. For each animal, the total epithelial area was obtained by pooling the values recorded for each of the 10 bronchiolar profiles. The number of CC16-positive epithelial cells was also recorded for each bronchiolar profile and these values pooled for one section. The density of CC16 immunoreactive cells was then calculated for each animal and expressed as the number of positive cells per $100 \mathrm{~mm}^{2}$ of bronchiolar epithelium. Individual data were pooled per experimental group.

\section{Analytical methods}

CC16 concentrations were determined by an automated latex immunoassay, as described previously [5]. This assay uses as a standard the rat protein purified from concentrated BALF and a polyclonal antibody raised in rabbits [5]. By Western blotting analysis, this antibody 
demonstrated the presence of a single band at $\sim 16 \mathrm{kDa}$ when tested in different biological fluids [5]. The performance of the assay in various rat biological fluids including BALF and serum were similar to that reported for the human protein $[5,21]$. In particular, the analytical recovery, tested by adding $50 \mathrm{ng}$ of purified rat $\mathrm{CC} 16$ to 1 $\mathrm{mL}$ of 10 different sera, averaged $90 \pm 7 \%$ and the detection limit was $0.5 \mu \mathrm{g} \cdot \mathrm{L}^{-1}$. Albumin concentrations were determined by latex immunoassay calibrated with a pool of normal sera (albumin concentration $30 \mathrm{~g} \cdot \mathrm{L}^{-1}$ ). Lactate dehydrogenase (LDH) activity was assayed by monitoring the reduction of oxidized nicotinamide adenine dinucleotide $\left(\mathrm{NAD}^{+}\right)$at $340 \mathrm{~nm}$ in the presence of lactate. Alkaline phosphatase was assayed enzymatically using a commercial reagent kit (Bayer Diagnostics, Leverkusen, Germany). Creatinine was determined in serum by the method of Jaffé.

\section{Northern enzyme-linked immunosorbent assay for CC16}

Total lung ribonucleic acid (RNA) isolation was performed using TRIZOL reagent (GIBCO BRL, Merelbeke, Belgium) according to manufacturer's instructions. $\beta$-Actin and CC16 messenger RNA (mRNA) levels were measured in $1 \mu \mathrm{g}$ of total lung RNA using a Northern enzyme-linked immunosorbent assay (ELISA) kit (Boehringer Mannheim, Mannheim, Germany) with some modifications to the manufacturer's protocol. Instead of labelling poly(A)+ mRNA with biotin for mRNA capture on streptavidincoated microtitre plates, $5^{\prime}$-biotinylated deoxyribonucleic acid (DNA) probes specific for rat $\beta$-actin and $\mathrm{CC} 16$ were used to capture mRNA in the total RNA. The second nonoverlapping DNA probe for mRNA detection was labelled by incorporation of digoxigenin (DIG)-deoxyuridine triphosphate (dUTP) (Boehringer Mannheim) during amplification. The probes were generated by the polymerase chain reaction (PCR) starting with cloned rat $\beta$-actin and CC16 complementary DNA (cDNA). The specific primers used for the amplification of the $\beta$-actin probes were: 5'-AGTCACTCCAAGTATCCACG-3' and 5' -biotinGTCTCACGTCAGTGTACAGG-3' for the biotin-labelled probe, and 5'-CCATCCTGCGTCTGGACCTG-3' and 5'-CTCATCGTACTCCTGCTTGC-3' for the DIG-labelled probe. The primers used for the amplification of the CC16 probe were $5^{\prime}$-TGCCTCAGACCTGCAAAATG-3' and 5'-biotin-GGGCTTTAGCGTAGAATATCT-3' for the biotin-labelled probe, and 5'-CATCAGCCCACATCTACAGAC-3' and 5'-AGACTCTGAGCCTAGGAGGA-3' for the DIG-labelled probe. In each measurement for $\beta$ actin or CC16 mRNA, a standard curve with a dilution series of total RNA was used for reliable quantification of the transcripts. CC16 mRNA data were normalized to $\beta$ actin mRNA levels.

\section{Statistical analysis}

Results are expressed as mean $\pm \mathrm{SD}$. Differences between groups were assessed by one-way analysis of variance followed by the Student-Newman-Keuls multiple comparison test. When the variances were nonuniform, the data were subjected to $\log$ transformation prior to statistical analysis. Associations between variables were assessed by calculating the Pearson's correlation coefficient. The level of critical significance was assigned at $\mathrm{p}<0.05$.

\section{Results}

\section{Histological analysis}

Histological lesions induced by IPO mainly involved Clara cells that presented a swollen apical cytoplasm frequently protruding into the bronchiolar lumen. Alveolar and bronchiolar ciliated cells were not affected by the IPO treatment. In MMT-treated rats, no abnormalities were seen in the alveolar and the bronchiolar epithelia with the exception of isolated Clara cells sloughing in the lumen (fig. 1). ANTU induced gross macroscopic changes consisting of pulmonary petechiae with marked pleural effusion and was fatal in two animals. Microscopically, discrete zones of alveolar oedema in lung parenchyma and a sloughing of Clara cells comparable to that seen with MMT were observed.

\section{CC16 in BALF and serun}

The concentration of $\mathrm{CC} 16$ was significantly decreased in the BALF of all treated groups. As shown in figure 2, IPO produced the most important reduction $(80 \%$ on average), followed by MMT (60\%) and ANTU (40\%). Interestingly, in serum, CC16 showed the opposite pattern of that in BALF, increasing on average by $300 \%$ with ANTU, 200\% with IPO, and 135\% with MMT.

\section{Other parameters}

The three lung toxicants produced a significant elevation of albumin concentrations in BALF which, on average, reached values 4-, 20- and 80-times that of controls in rats treated with IPO, MMT and ANTU, respectively (fig. 3). The activity of LDH and alkaline phosphatase in BALF was increased only by the IPO treatment (fig. 3). A statistically significant increase of serum creatinine was noted in the treated groups, but this elevation was slight and similar between the three toxicants (controls $8 \pm 1.1$ $\mathrm{mg} \cdot \mathrm{L}^{-1}$; IPO $10.1 \pm 1.5 \mathrm{mg} \cdot \mathrm{L}^{-1}$; ANTU $9.8 \pm 1.1 \mathrm{mg} \cdot \mathrm{L}^{-1}$; MMT $\left.9.1 \pm 1.6 \mathrm{mg} \cdot \mathrm{L}^{-1} ; \mathrm{p}=0.001\right)$.

\section{CC16 immunostaining and Northern ELISA analysis}

When using polyclonal anti-rat CC16 antibody, CC16positive cells were localized in the terminal bronchioles, where they represent the predominant epithelial cell type (fig. 1). No immunostaining was detected in the alveolar cells. In treated animals, the bronchiolar epithelium was characterized by a partial loss of the normal CC16-immunoreactive Clara cell profile. This was confirmed by a computer-assisted morphometric analysis showing that the density of Clara cells was significantly lower in the bronchiolar epithelium of treated rats, compared to controls (fig. 4). The diminution of the number of CC16immunoreactive cells was mainly apparent following IPO treatment and occurred with less severity following MMT and ANTU treatments. A comparable pattern of changes was observed when evaluating the CC16 mRNA levels with a Northern ELISA (fig. 4). The CC16/ $\beta$-actin mRNA ratio was significantly decreased by IPO and MMT. The ratio was also decreased following ANTU treatment but without reaching the level of statistical significance $(\mathrm{p}=$ $0.1)$. 

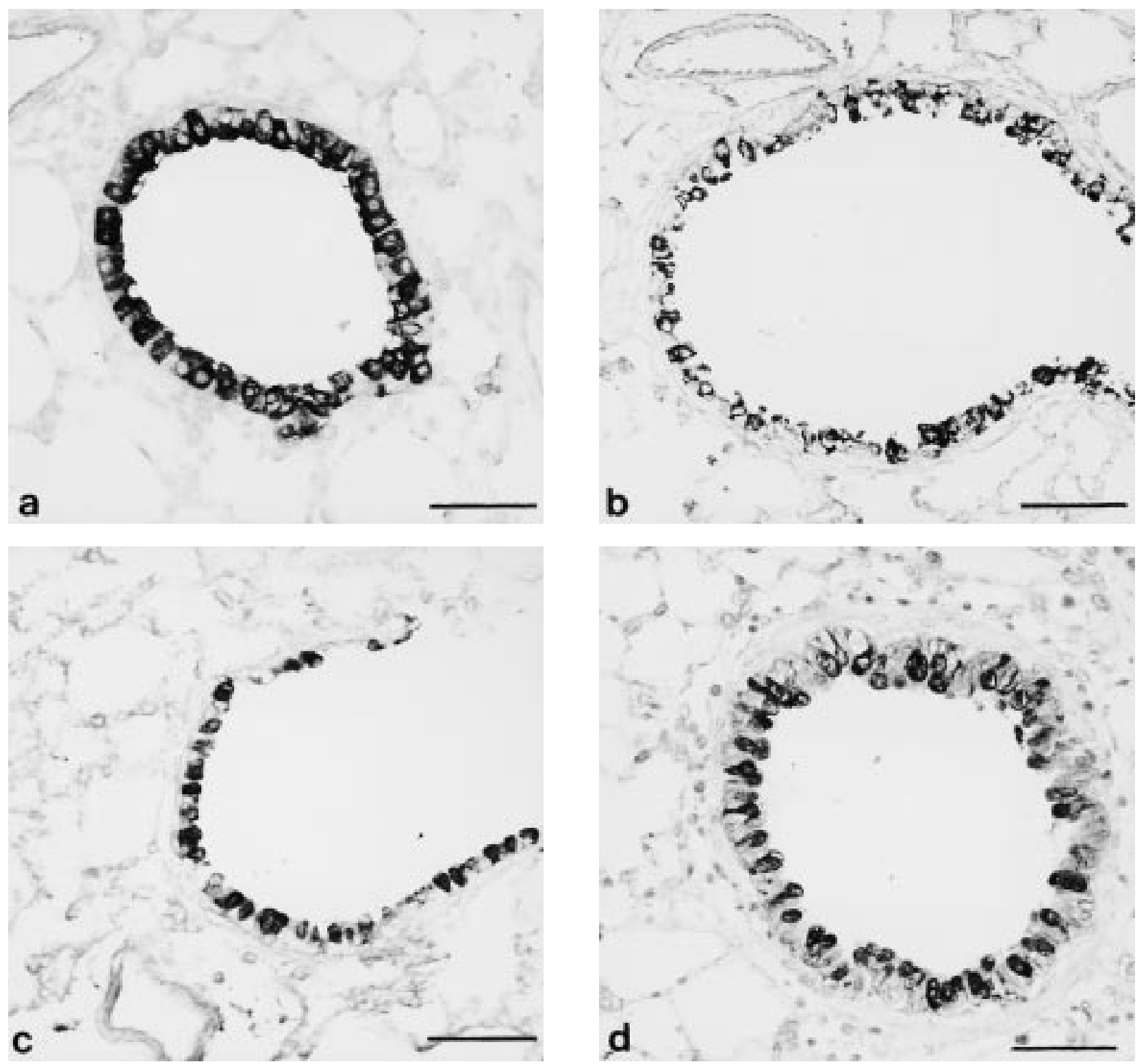

Fig. 1. - Immunolocalization of Clara cells in terminal bronchioles in the lungs of control rats (a), rats treated for $6 \mathrm{~h}$ with methylcyclopentadienyl manganese tricarbonyl (MMT; b) or $\alpha$-naphthylthiourea (ANTU; c), and rats treated for $24 \mathrm{~h}$ with 4-ipomeanol (IPO; d). The immunostaining was performed using a polyclonal anti-rat CC16 antibody. In control lungs (a), the Clara cells are intensely stained and represent the predominant epithelial cell type of the bronchiolar epithelium. In the treated rat, (b, c and d), the bronchiolar epithelium is characterized by a partial loss of the normal CC16immunoreactive Clara cell profile. Note the partially necrotic aspect of the bronchiolar epithelium in MMT-treated rats (b) and the characteristic apical swelling of Clara cells after short treatment with IPO (d). (Internal scale bars $=50 \mu \mathrm{m}$.)

\section{Correlations}

In the control rats, the $\mathrm{CC} 16$ concentration in serum was significantly correlated with that in BALF (fig. 5), but not with the albumin level in BALF $(\mathrm{n}=20, \mathrm{r}=0.049$, $\mathrm{p}=0.845)$. In treated rats examined separately or combined, no association between CC16 in serum and BALF parameters was observed. However, when control and treated rats were combined $(\mathrm{n}=48)$, a significant correlation emerged between the elevation in serum of $\mathrm{CC} 16$ and the increase in BALF of both LDH $(r=0.31, \mathrm{p}=0.03)$ and albumin (fig. 6). The $\mathrm{CC} 16$ level in serum also showed a weak negative correlation with that in BALF $(r=-0.32$, $\mathrm{p}=0.026$ ). In BALF, the concentration of CC16 was negatively correlated with the levels of albumin $(r=-0.32, p=$
$0.02)$, alkaline phosphatase $(\mathrm{r}=-0.51, \mathrm{p}=0.0002)$ and LDH $(\mathrm{r}=-0.70, \mathrm{p}=0.0001)$. Also of note was that the CC16 level in BALF was correlated with the number of CC16immunoreactive cells determined in control and treated rats, but this did not reach a level of statistical significance $(\mathrm{n}=15, \mathrm{r}=0.47, \mathrm{p}=0.07)$.

\section{Discussion}

The objective of the present study was to provide an experimental basis for the interpretation of changes to CC16 concentrations in pulmonary and extrapulmonary fluids. CC16 levels were determined in these two fluids by a sensitive immunoassay in normal rats and rats with 

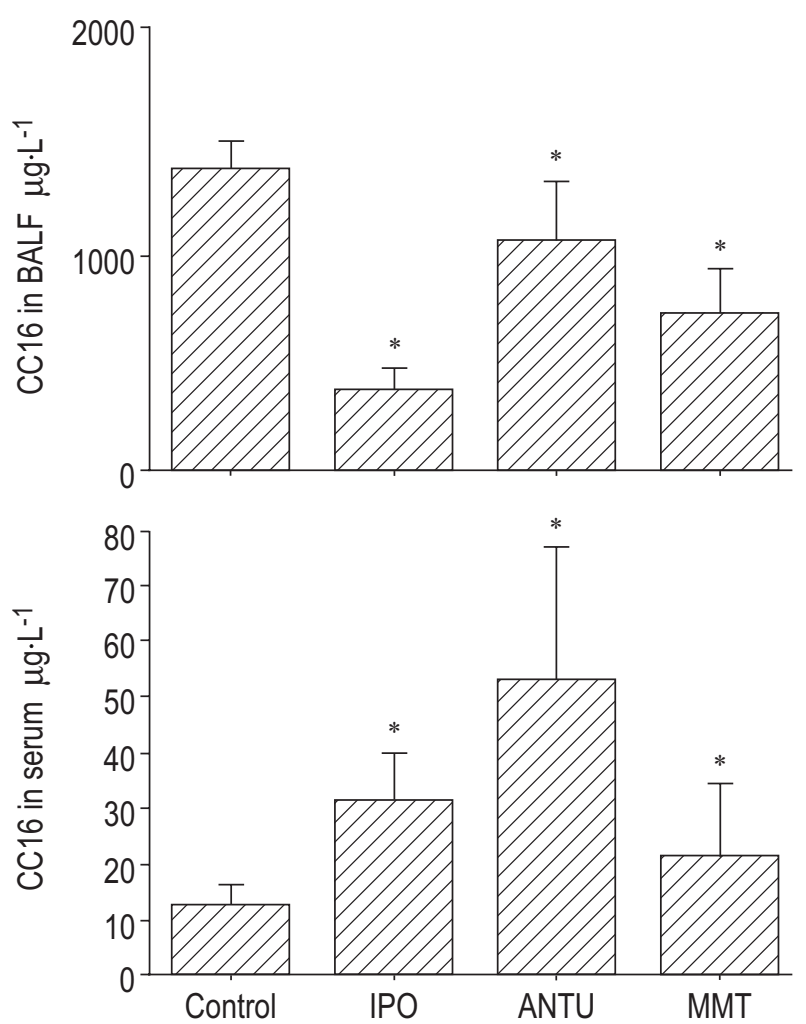

Fig. 2. - Concentrations of the $16 \mathrm{kDa}$ Clara cell protein $(\mathrm{CC} 16)$ in bronchoalveolar lavage fluid (BALF) and serum in rats given a single i.p. injection of 4-ipomeanol (IPO $8 \mathrm{mg} \cdot \mathrm{kg}^{-1}$ ), $\alpha$-naphthylthiourea (ANTU $5 \mathrm{mg} \cdot \mathrm{kg}^{-1}$ ) and methylcyclopentadienyl manganese tricarbonyl (MMT $5 \mathrm{mg} \cdot \mathrm{kg}^{-1}$ ). Samples were taken $24 \mathrm{~h}$ (IPO and controls) or $6 \mathrm{~h}$ (ANTU and MMT) after administration. Data are expressed as mean $\pm \mathrm{SD}$, with each group containing $8-10$ rats. *: $p<0.05$, significantly different from the control group (ANOVA followed by Student-Newman-Keuls test).

epithelial or endothelial lung injury induced by systemic toxicants. The purpose was not to study the intrinsic toxicity of these agents, but to use them as model compounds to investigate the $\mathrm{CC} 16$ changes in BALF and serum. Possible mechanisms leading to changes of $\mathrm{CC} 16$ in these biological fluids were investigated by evaluating the CC16-immunoreactive cell density, the gene expression and usual biochemical BALF parameters, including albumin, as indicators of the BA/BB integrity.

The results obtained in normal rats were consistent with those reported in humans. CC16 appeared as a major BALF protein with a concentration averaging $4 \%$ of that of albumin [2]. In serum, the CC16 level was two orders of magnitude lower than that in BALF. As in humans, the concentration of $\mathrm{CC} 16$ in serum correlated with that in BALF $[2,3,5]$, which supports the view that serum CC16 derives mostly, if not exclusively, from the respiratory tract, with other sex-linked sources such as the uterus [22] contributing nothing or very little to the serum CC16 concentrations. In humans, this was recently confirmed by multiple tissue Northern blot analysis on 50 different tissues (Human RNA Master Blot ${ }^{\mathrm{TM}}$, Clontech) demonstrating that CC16 is expressed almost exclusively in the respiratory tract, with the exception of a very weak expression in the urogenital tract (C. Hermans, unpublished data). It is worth noting that the proportion of Clara cells in the rat bronchiolar epithelium appeared to be much
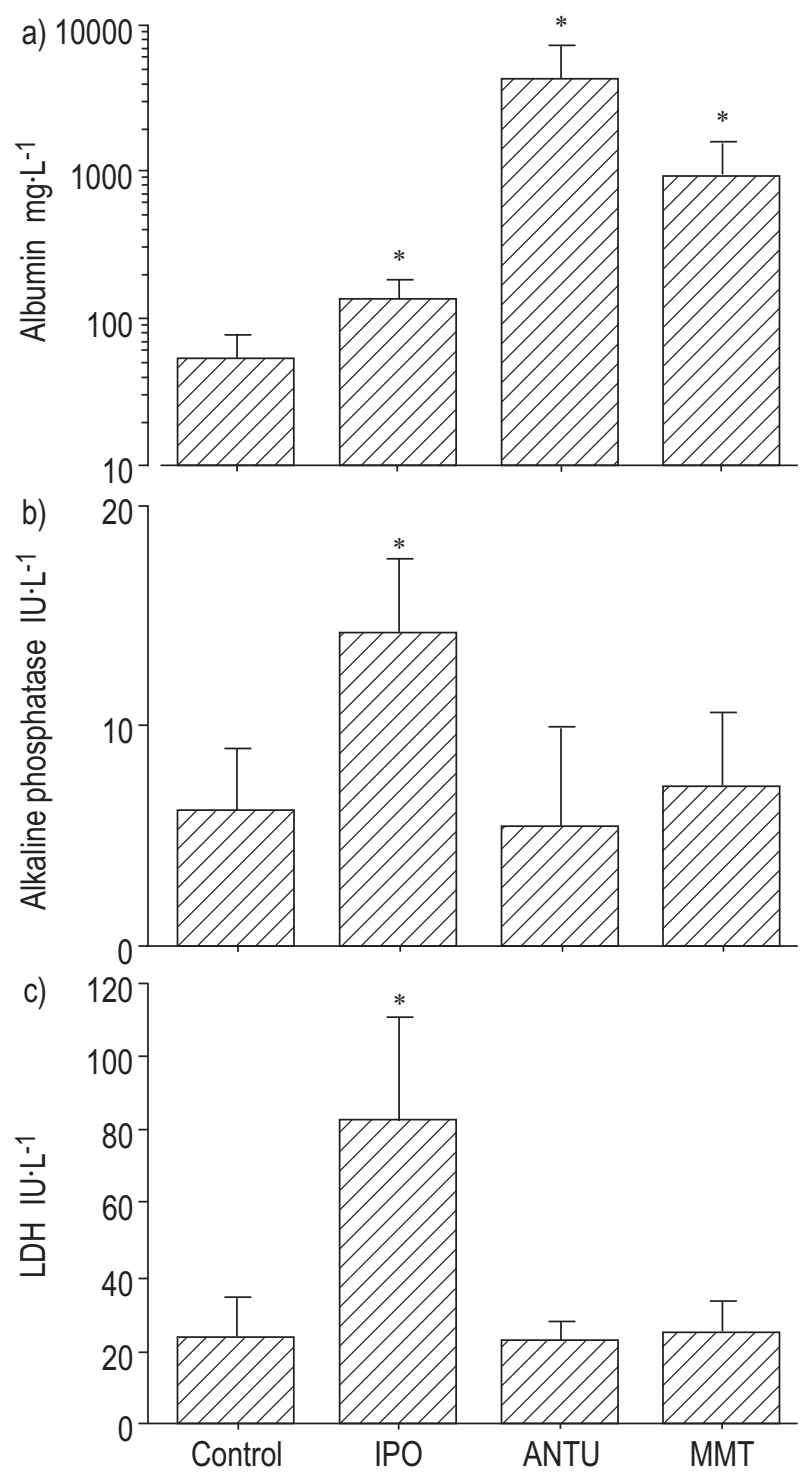

Fig. 3. - Concentrations of a) albumin, b) alkaline phosphate and c) lactate dehydrogenase (LDH) in bronchoalveolar lavage fluid (BALF) of control rats and rats challenged with 4-ipomeanol (IPO), $\alpha$-naphthylthiourea (ANTU) or methylcyclopentadienyl manganese tricarbonyl $(\mathrm{MMT})$. Data are expressed as mean $\pm \mathrm{SD}$, with each group containing $8-$ 10 rats. *: $\mathrm{p}<0.05$, significantly different from the control group (ANOVA followed by Student-Newman-Keuls test).

higher than in humans. In the present study, CC16positive cells represented $\sim 80 \%$ of total bronchiolar cells, an estimate very close to that derived from ultrastructural analyses [23], but about three-times higher than that in humans [3].

Lung injury was induced by well-known pneumotoxicants active in rats following systemic administration. Small doses of these agents were used in order to produce mild pulmonary injury with little lethality and to avoid toxic effects on organs other than the lung. Sacrifice of the rats was performed shortly after challenge because at a later stage direct toxic effects on CC16 levels could not be detected in view of the short half-life of the protein in serum (estimated to be a few hours) [9] and the proliferation of Clara cells acting as progenitor cells during tissue repair [24]. As confirmed by histological examination and 

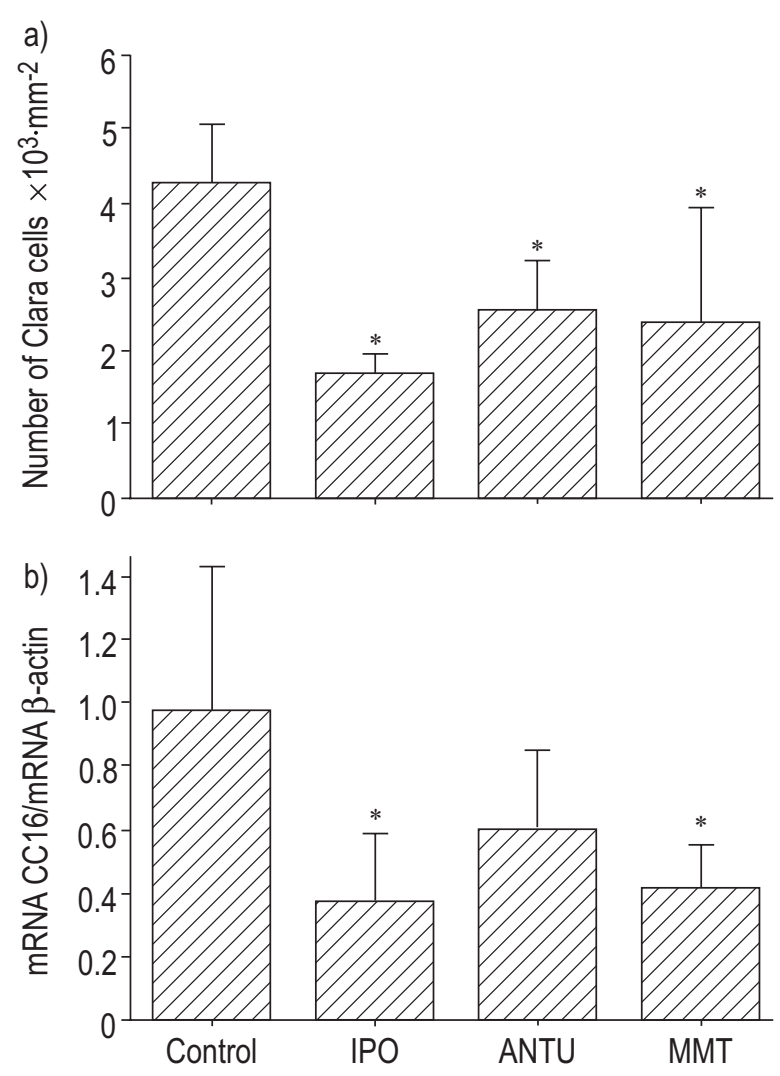

Fig. 4. - Numerical density of Clara cells (a) and the $16 \mathrm{kDa}$ Clara cell protein $(\mathrm{CC} 16) / \beta$-actin messenger ribonucleic acid (mRNA) ratio (b) in control rats and rats given a single i.p. injection of 4-ipomeanol (IPO), $\alpha$-naphthylthiourea (ANTU) and methylcyclopentadienyl manganese tricarbonyl (MMT). Data are expressed as mean $\pm \mathrm{SD}$, with each group containing 3-5 rats. $*$ : $p<0.05$, significantly different from the control group (ANOVA followed by Student-Newman-Keuls test).

in agreement with the literature, lesions induced by IPO and MMT were predominantly confined to Clara cells, with other sites and cell types of the respiratory tract being spared. This specificity was achieved partly because of the intrinsic toxicity of these compounds which are bioactivated within Clara cells [25-27], and partly, as in the case of MMT, by the time of sacrifice, since alveolar cell damage has been described at a more advanced stage of intoxication [13]. As expected, ANTU caused alveolar oedema in discrete zones of the lung parenchyma [16]. This compound also caused some sloughing of Clara cells, an effect previously unnoticed but which may be explained by its bioactivation within Clara cells $[16,28]$.

These three toxicants induced a significant reduction of CC16 in BALF which can undoubtedly be ascribed to Clara cell damage with an ensuing decreased production of the protein as confirmed by the histological examination, the correlation between $\mathrm{CC} 16$ and classical indices of lung injury in BALF, as well as the study of CC16 transcripts and CC16-immunoreactive cells. These results are in keeping with those obtained with naphthalene and bleomycin which have been shown to produce marked changes in CC16 expression in mice lungs as estimated by in situ hybridization $[29,30]$. The present observations indicate that the measurement of CC16 in BALF can be used as a sensitive surrogate of the number and/or integrity of Clara cells.

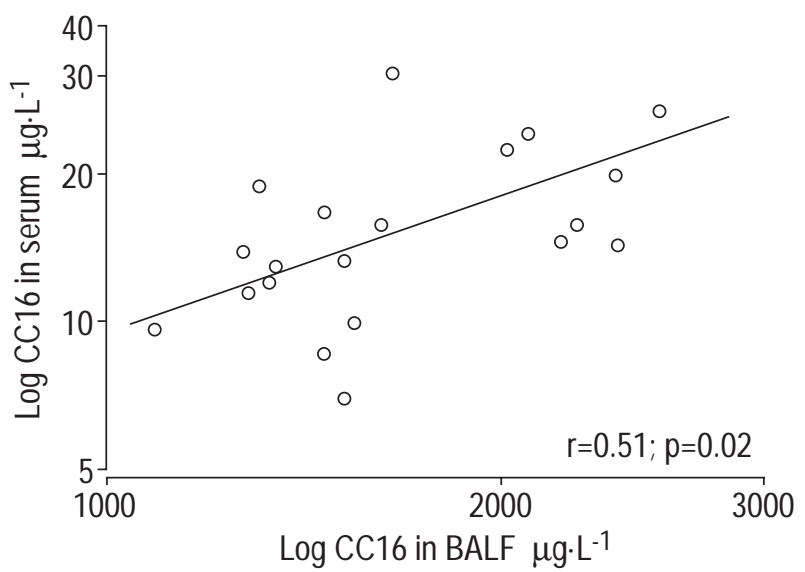

Fig. 5. - Correlation between the $16 \mathrm{kDa}$ Clara cell protein $(\mathrm{CC} 16)$ in serum and in bronchoalveolar lavage fluid (BALF) in control rats $(n=$ 20).

In serum however, the CC16 concentration was increased in all treated groups, with a pattern of changes opposite to those in BALF, and which correlated with the severity of the lung injury as assessed by BALF biochemical indices. This elevation, of course, cannot be related to the synthesis and secretion of the protein in the respiratory tract which, on the contrary, were diminished. Another possible explanation would be a reduced renal clearance $[2,9]$, but this possibility is refuted by the fact that none of these toxicants have been reported to be nephrotoxic at the doses used in the present study, which was confirmed by the observed levels of serum creatinine. The only remaining explanation is that there was an increased leakage of $\mathrm{CC} 16$ from the respiratory tract into the plasma secondary to alteration of the BA/BB. The determination in BALF of high molecular weight plasma proteins such as albumin is commonly used to assess the integrity and/or the permeability of the $\mathrm{BA} / \mathrm{BB}[31,32]$. The most pronounced increase of BALF albumin was observed in the group treated with ANTU, a potent oedematogenic agent damaging to lung endothelial cells [17]. An increase in the BALF albumin content also followed IPO and MMT treatments, most probably as a

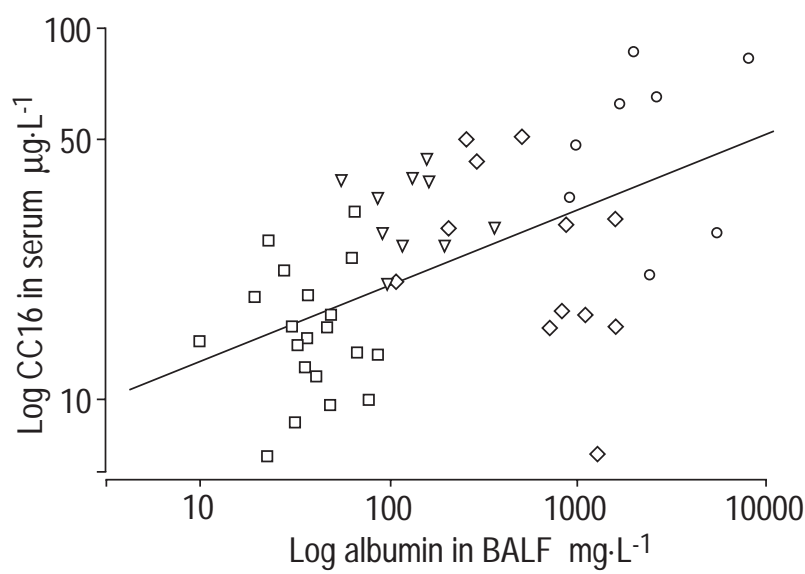

Fig. 6. - Correlation between serum $16 \mathrm{kDa}$ Clara cell protein $(\mathrm{CC} 16)$ and albumin in bronchoalveolar lavage fluid (BALF) in control rats ( $\square$ ) and rats treated with 4-ipomeanol $(\nabla), \alpha$-naphthylthiourea $(\bigcirc)$ and methylcyclopentadienyl manganese tricarbonyl $(\diamond)$. 
result of epithelial or endothelial cell damage. Interestingly, the most important CC16 increase in serum was observed in rats treated with ANTU which developed the most severe damage of the air-blood barrier. On average, the pattern of increase in albumin in the BALF of treated rats was parallel to that found for $\mathrm{CC} 16$ in serum and when considering all animals, both appear significantly correlated, which is clearly indicative of a leakage of $\mathrm{CC} 16$ across the $\mathrm{BA} / \mathrm{BB}$, similar to that of albumin but in the opposite direction.

The exact mechanism by which $\mathrm{CC} 16$ enters into plasma remains to be determined. In control rats, the most plausible explanation is that of a diffusion of the protein from the lumen of the respiratory tract across the BA/BB. The significant correlation between CC16 levels in serum and BALF of control rats supports this hypothesis of a diffusional exchange, the driving force for this process being provided by the huge $\mathrm{CC} 16$ concentration gradient between the epithelial lining fluid and plasma [5]. It is of interest to note that in view of its sieving properties, the $\mathrm{BA} / \mathrm{BB}$ probably offers little hindrance to the passage of $\mathrm{CC} 16$ (molecular radius of $1.9 \mathrm{~nm}$ ) as it is believed to function as an heteroporous membrane with a predominant population of small pores (radii between 0.5 and 2.5 $\mathrm{nm}$ ) and a small population of much larger pores [33, 34].

If there is little doubt that the increase of serum CC16 with lung injury is due to its increased leakage from the lung, it remains to be determined whether this is the result of an increased permeability of the $\mathrm{BA} / \mathrm{BB}$, of fluid transfer across the $\mathrm{BA} / \mathrm{BB}$, or both. In this respect, it is worth noting that the leakage of albumin and of $\mathrm{CC} 16$ across the $\mathrm{BA} / \mathrm{BB}$ barrier were significantly correlated for all rats combined, but not within each treated group. Several explanations can be proposed for this poor correlation between both indices, all of which are related to the difference in size between the two proteins. Firstly, if the heteroporous models proposed to account for the sieving properties of the BA/BB are correct [33, 34], CC16 should move almost freely across the $\mathrm{BA} / \mathrm{BB}$ and, in contrast to albumin, its passage should be relatively unaffected by a loss of the selective permeability of the BA/BB. Secondly, albumin and other high molecular weight plasma proteins leaking into the respiratory tract accumulate in small quantities in the alveolar and bronchiolar lining fluids from where they are cleared very slowly [35]. This results in a progressive building up of the albumin concentration in the epithelial lining fluid, which probably explains why the albumin level in BALF can increase by several orders of magnitude in lung injury. The situation is completely different with $\mathrm{CC} 16$ leaking through the $\mathrm{BA} / \mathrm{BB}$ which dilutes into the bloodstream from where it is rapidly eliminated by glomerular filtration. Finally, as CC16 is a short-lived protein in plasma, its kinetics following acute lung damage probably differ from those of albumin in BALF, which may further explain the poor correlation between the two indices. Although the mechanisms governing the passage of proteins are poorly understood, the sieving properties of the $\mathrm{BA} / \mathrm{BB}$, allowing an unrestricted diffusion of $\mathrm{CC} 16$, as well as the poor correlation with albumin in BALF, may indicate that the escape of $\mathrm{CC} 16$ is related more to an increased convection by a hypothetical drag effect whereas a loss of the selective permeability of the BA/BB would be responsible for the leakage of albumin.
The hypothesis that $\mathrm{CC} 16$ in serum rises as a result of its increased leakage across the $\mathrm{BA} / \mathrm{BB}$ is suggested by recent observations in humans. An increase in CC16 has been found in firefighters acutely exposed to fire smoke as well as in patients with interstitial lung diseases such as pulmonary fibrosis and sarcoidosis, and is most probably a result of acute or chronic damage of the BA/BB [2, 7-9]. Similar findings have been made with other lung secretory proteins. Two surfactant-associated proteins (SP-A and SP-B), synthesized by alveolar type II cells and/or Clara cells, were recently found to be increased in the serum of patients with acute respiratory distress syndrome (ARDS) [36, 37], a condition characterized by increased permeability and loss of size-selectivity of the barrier [38]. This increase occurs despite a decrease in the levels of SP-A and SP-B in lung lavage fluids of ARDS patients [39]. These observations support the hypothesis that the damage to the $\mathrm{BA} / \mathrm{BB}$ induces an increase in the bidirectional flux of proteins between serum and the lumen of the respiratory tract resulting in the development of protein-rich pulmonary oedema and the leakage of lung secretory proteins into the bloodstream. The terms "pneumoprotein" and "pneumoproteinaemia" have recently been proposed to refer to such lung secretory proteins and their occurrence in plasma [40]. The present observations indicate that lung secretory proteins can simultaneously decrease in BALF and increase in serum, suggesting that the permeability of the $\mathrm{BA} / \mathrm{BB}$ is a more important determinant of their circulating levels than their absolute levels at the surface of the respiratory tract.

In conclusion, this study suggests that in lung injury induced by different lung toxicants, changes in levels of the $16 \mathrm{kDa}$ Clara cell protein in serum are mainly affected by the integrity and/or the permeability of the bronchoalveolar/blood barrier. In bronchoalveolar lavage fluid by contrast, the concentration of the $16 \mathrm{kDa}$ Clara cell protein is mainly determined by the number and/or the integrity of Clara cells of which it can be used as a sensitive surrogate. These observations should contribute to a better understanding of the changes of lung secretory proteins, not only in bronchoalveolar lavage fluid, but also in serum where the $16 \mathrm{kDa}$ Clara cell protein might find widespread applications as a noninvasive indicator of damage to Clara cells or to the bronchoalveolar/blood barrier.

Acknowledgements. The authors gratefully acknowledge Fr. Verschaeve and J. Casters for their expert technical assistance.

\section{References}

1. Singh G, Singh J, Katyal SL, et al. Identification, cellular localization, isolation and characterization of human Clara cell-specific $10 \mathrm{kDa}$ protein. J Histochem Cytochem 1988; 36: 73-80.

2. Bernard A, Marchandise FX, Depelchin S, Lauwerys R, Sibille Y. Clara cell protein in serum and bronchoalveolar lavage. Eur Respir J 1992; 5: 1231-1238.

3. Shijubo N, Itoh Y, Yamaguchi T, et al. Serum and BAL Clara cell $10 \mathrm{kDa}$ protein $(\mathrm{CC} 10)$ levels and $\mathrm{CC} 10$ positive bronchiolar cells are decreased in smokers. Eur Respir J 1997; 10: 1108-1114.

4. Gupta RP, Patton SE, Jetten AM, Hook GER. Purification, characterization and proteinase-inhibitory activity of a Clara-cell secretory protein from the pulmonary extracellular lining of rabbits. Biochem J 1987; 248: 337-344. 
5. Halatek T, Hermans C, Broeckaert F, et al. Quantification of Clara cell protein in rat and mouse biological fluids using a sensitive immunoassay. Eur Respir J 1998; 11: 726-733.

6. Bernard A, Roels H-A, Buchet J-P, Lauwerys R. Decrease of serum Clara cell protein in smokers. Lancet 1992; 339: 1620 (Letter).

7. Lesur O, Bernard A, Arsalane K, et al. Clara cell protein (CC16) induces a phospholipase A2-mediated inhibition of fibroblast migration in vitro. Am J Respir Crit Care Med 1995; 152: 290-297.

8. Bernard A, Hermans C, Van Houte G. Transient increase of serum Clara cell protein (CC16) after exposure to smoke. Occup Environ Med 1997; 54: 63-65.

9. Hermans C, Bernard A. The Clara cell protein (CC16): characteristics and potential applications as biomarker of lung toxicity. Biomarkers 1996; 1: 3-8.

10. Boyd MR. Evidence for the Clara cell as a site of cytochrome P450-dependent mixed-function oxidase activity in lung. Nature 1977; 269: 713-715.

11. Sabo JP, Kimmel EC, Diamond L. Effects of the Clara cell toxin, 4-ipomeanol, on pulmonary function in rats. $J \mathrm{Appl}$ Physiol 1983; 54: 337-344.

12. Doster AR, Farrell RL, Wilson BJ. An ultrastructural study of bronchiolar lesions in rats induced by 4-ipomeanol, a product from mold-damaged sweet potatoes. $A m J$ Pathol 1983; 111: 56-61.

13. Hakkinen PJ, Haschek WM. Pulmonary toxicity of methylcyclopentadienyl manganese tricarbonyl: nonciliated bronchiolar epithelial (Clara) cell necrosis and alveolar damage in the mouse, rat, and hamster. Toxicol Appl Pharmacol 1982; 65: 11-22.

14. McGinley PA, Morris JB, Clay RJ, Gianutsos G. Disposition and toxicity of methylcyclopentadienyl manganese tricarbonyl in the rat. Toxicol Lett 1987; 36: 137-145.

15. Day BJ, Carlson GP, DeNicola DB. Gamma-glutamyltranspeptidase in rat bronchoalveolar lavage fluid as a probe of 4-ipomeanol and alpha-naphthylthiourea-induced pneumotoxicity. J Pharmacol Methods 1990; 24: 1-8.

16. Boyd MR, Neal RA. Studies on the mechanism of toxicity and of development of tolerance to the pulmonary toxin alpha-naphthylthiourea (ANTU). Drug Metab Dispos 1976; 4: 314-322.

17. Cunningham AL, Hurley JV. Alpha-naphthylthioureainduced pulmonary oedema in the rat: a topographical and electron-microscope study. J Pathol 1972; 106: 25-35.

18. Nilaver G, Kozlowski GP. Comparison of the PAP and ABC immunocytochemical techniques. In: Bullock GR, Petrusz P, eds. Techniques in Immunocytochemistry. London, Academic Press, 1989; pp. 199-215.

19. Bankfalvi A, Navabi H, Bier B, Böcker W, Jasani B, Schmid KW. Wet autoclave pretreatment for antigen retrieval in diagnostic immunohistochemistry. J Pathol 1994; 174: 223-228.

20. Nonclercq D, Wrona S, Toubeau G, et al. Tubular injury and regeneration in the rat kidney following acute exposure to gentamicin: a time-course study. Ren Fail 1992; 14: 507-521.

21. Bernard A, Lauwerys R, Noel A, Vandeleene B, Lambert A. Determination by latex immunoassay of protein 1 in normal and pathological urine. Clin Chim Acta 1991; 201: 213-246.

22. Hagen G, Wolf M, Katyal SL, Singh G, Beato M, Suske G. Tissue-specific expression, hormonal regulation and 5 flanking gene region of the rat Clara cell $10 \mathrm{kDa}$ protein comparison to rabbit uteroglobin. Nucleic Acids Res 1990; 18: 2939-2946.
23. Plopper CG, Hyde DM, Buckpitt AR. Clara cells. In: Crystal RG, West JB, Weibel ER, Barnes PJ, eds. The Lung Scientific Foundation. New York, LippincottRaven, 1997; pp. 517-533.

24. Evans MJ, Cabral-Anderson LJ, Freeman G. Role of the Clara cell in the renewal of the terminal bronchiolar epithelium in the rat. Lab Invest 1978; 38: 648-645.

25. Verschoyle RD, Philpot RM, Wolf CR, Dinsdale D. CYP4B1 activates 4-ipomeanol in rat lung. Toxicol Appl Pharmacol 1993; 123: 193-198.

26. Versehoyle RD, Wolf CR, Dinsdale D. Cytochrome P450 2B isoenzymes are responsible for the pulmonary bioactivation and toxicity of butylated hydroxytoluene, $\mathrm{O}, \mathrm{O}, \mathrm{S}$-trimethylphosphorothiothate and methylcyclopentadienyl manganese tricarbonyl. J Pharmacol Exp Ther 1993; 266: 958-963.

27. Blanchard KT, Clay RJ, Morris JB. Pulmonary activation and toxicity of cyclopentadienyl manganese tricarbonyl. Toxicol Appl Pharmacol 1996; 136: 280-288.

28. Dinsdale D. Lung injury: cell-specific bioactivation/deactivation of circulating pneumotoxins. Int $J$ Exp Pathol 1995; 76: 393-401.

29. Stripp BR, Maxson K, Mera R, Singh G. Plasticity of airway cell proliferation and gene expression after acute naphthalene injury. Am J Physiol 1995; 269: L791-L799.

30. Daly HE, Baecher-Allan CM, Barth RK, D'Angio CT, Finkelstein JN. Bleomycin induces strain-dependent alterations in the pattern of epithelial cell-specific marker expression in mouse lung. Toxicol Appl Pharmacol 1997; 142: 303-310.

31. Bell DY, Haseman JA, Spock A, McLennan G, Hook GE. Plasma proteins of the bronchoalveolar surface of the lungs of smokers and non-smokers. Am Rev Respir Dis 1981; 124: 72-79.

32. Jones KP, Edward JH, Reynolds SP, Peters TJ, Davies $\mathrm{BH}$. A comparison of albumin and urea as reference markers in bronchoalveolar lavage fluid from patients with interstitial lung disease. Eur Respir J 1990; 3: 152-156.

33. Conhaim RL, Eaton A, Staub NC, Heath TD. Equivalent pore estimate for the alveolar-airway barrier in isolated dog lung. J Appl Physiol 1988; 64: 1134-1442.

34. Taylor AE, Gaar KA Jr. Estimation of equivalent pore radii of pulmonary capillary and alveolar membranes. $\mathrm{Am}$ J Physiol 1970; 218: 1133-1140.

35. Folkesson HG, Matthay MA, Weström BR, Kim M, Karlsson BW, Hastings RH. Alveolar epithelial clearance of protein (brief review). J Appl Physiol 1996; 80: 14311445.

36. Doyle IR, Nicholas TE, Bersten AD. Serum surfactant protein-A in patients with acute cardlogenic pulmonary edema and adult respiratory distress syndrome. Am J Respir Crit Care Med 1995; 152: 307-317.

37. Doyle IR, Nicholas TE, Bersten AD. Surfactant proteins (SP-A \& SP-B) in plasma in critically ill patients with respiratory disease. Am J Respir Crit Care Med 1997; 156: $1217-1229$.

38. Holter JF, Weiland JE, Pacht ER, Gadek JE, Davis WB. Protein permeability in the adult respiratory distress syndrome. Loss of size selectivity of the alveolar epithelium. $J$ Clin Invest 1986; 78: 1513-1522.

39. Gregory T, Longmore W, Moxley M, et al. Surfactant chemical composition and biophysical activity in acute respiratory distress syndrome. J Clin Invest 1991; 65: 1976-1981.

40. Hermans C, Bernard A. Pneumoproteinaemia: a new perspective in the assessment of lung disorders. Eur Respir $J$ 1998; 11: 801-803. 